\title{
Obituaries: A Dead Important Genre
}

\author{
Clare Brant
}

King's College London

\section{ABSTRACT}

Obituaries are micro-narratives in which distinct conventions and tensions are at work. Humanist and historical, emotional and dispassionate, philosophical and random, obituaries have a literary nexus that encompasses reverence, irreverence, grief and (in some cases) relief. My analysis starts with broadsheet obituaries of the late twentieth century, and models of reading the genre, which I re-read through counter-establishment Private Eye's comic verse obituaries. Pet memorials adopt and adapt obituary, creating distinct subcultures of animal relations in genres of human mourning. The obituaries discussed span the ideological reproduction of essentially respectful obituaries, to comedy's counter-cultural critique, to an expansive embrace of selected animal companions seen as part of human families, to an articulation of the value of life forms lost to climate emergency. In these and other contexts, obituaries are alive and well.

Keywords: obituary, biography, animal, eco-grief

Obituaries have been curiously under-discussed as a genre, although they are obviously important in life writing. They act as the first version of a biography-sometimes the only one, although Wikipedia has closed the gap, with each life story seemingly waiting for a death sentence. Obituaries also have a less obvious relation to autobiography: as Quentin Crisp puts it, 'an autobiography is an obituary in serial form with the last installment missing. ${ }^{1}$ In this article I investigate a selection of obituaries to encompass some of the recent history of the genre and its possible future directions, including analysis of British broadsheet newspapers, ${ }^{2}$ satirical counterparts and non-human obituaries. These materials are 
connected by literary questions: what conventions and assumptions are at work? What do obituaries do for their subjects, and for their readers? Does the levelling power of death create a genre with no borders at all?

\section{BROADSHEET OBITUARIES IN BRITAIN}

The four broadsheet newspapers in Britain take their obituary subjects from the constituency of what used to be called 'the great and the good', now blurred by a democratic category written by readers: 'Other lives' (The Guardian) and 'Ordinary Lives' (The Times). Subjects include politicians, military figures, people from media, sports, arts and high society, and a few intellectuals. An obituary editor at The Daily Telegraph explains:

We publish around 1000 obituaries every year, writing maybe three or four times that number. And then we look at the claims of ten times more. But you never know who you'll be writing about next. God is our commissioning editor. ${ }^{3}$

The newspapers have staff writers whose job includes preparing and updating lives of the not-dead-yet; obituaries may also be written by professional associates, friends or admirers of the deceased. It is not common for detractors to be let loose, although there are sometimes complaints, corrections and addenda, and there is room for hostility, sneering and Addisonian damning with faint praise, usually contained by a British reluctance to be openly rude about the dead. There are some codes: 'He never married' used to mean the subject was gay.

Newspaper obituaries have distinct conventions including gatekeeping (who gets written about) and what one might call tone-originally avoiding the hyperbole and passion around global celebrities, for instance, and now simply managing it. The Daily Telegraph provides a great example with David Bowie. The text is a masterpiece of that waspish conciseness unique to obituaries:

David Bowie, who has died of cancer a few days after turning 69, was a rock musician of rare originality and talent; he was also, variously, a producer, painter, film actor, art critic, the progenitor of bisexual chic, a family man and an astute multi-millionaire. ${ }^{4}$

The obituary includes audio clips from Bowie's oeuvre and an invitation to vote for your favourite Bowie song. The Guardian, reminding us that Bowie was born David Jones in Brixton, focused on his musical reinventions, and also included a video tribute. ${ }^{5}$ So the old genre of print obituary has become multimedia in its online form. It has also had to adapt: 
first, to economic change. As Tim Bullamore, an obituarist on the Telegraph, observes,

Like a lot of newspaper journalism on both sides of the Atlantic, the obituary as an art form is in peril because of financial constraints. The material is there-fascinating people are still dying, and their stories remain to be told-but it can take time and money to dig out their stories. ${ }^{6}$

Second, broadsheet obituaries have adapted-and contributed to-the big post-millennium cultural changes around celebrity, death and mortality; these are beyond the scope of this article to address. Yet obituaries keep a simple template going. In Bullamore's words:

To my mind an obituary is NOT a news story: it may be worthy of a news story-who has died and how they died-in which case the News pages will run a paragraph or two. But the obituary is much, much more than a notification of death: it is the first attempt at a posthumous biography; it is an assessment of a life lived: with all the advantages and disadvantages that this person was born with, and with all the opportunities and difficulties that life threw at them, what did they make of their three score years and ten on this Earth?7

Genealogies of genre need to engage with changing attitudes to death, and hence to life-in-death writing. One scholar of obituaries, Nigel Starck, argues the genre takes off in Britain in the eighteenth century via the periodical The Gentleman's Magazine, a cultural and literary miscellany. ${ }^{8}$ That is a plausible starting point, reinforced by Elizabeth Barry who sees the obituary taking over from the verse epitaph, and widening to include different kinds of people newly famous for ephemeral skills and talents (such as singing, acting, feats of agility and memory, and eccentric talents) ${ }^{9}$ In Britain, the unexpected outpouring of sentiment following Princess Diana's death in 1997 was a watershed in reshaping public expressions of grief. The combination was reinforced and altered again by the death in 2009 of Jade Goody, 'ignoramus' star of reality TV, whose very public, slow and brave demise from cervical cancer led to heated debate between those who couldn't get enough of her life, death-in-waiting and death, and those scornful of the fuss. ${ }^{10}$ Digital media enabled mass memorialising practices which I can only touch on here; for instance, also in 2009, the unfortunately-named Michael Jackson Live website said, 'At this time of mourning for Michael Jackson, we are together in our sadness at the loss of one of the greatest entertainers ever. ${ }^{11}$ Especially for lives cut short, emotional power often appears in liquid images, as if imaging tears: outpourings of grief, tributes flooding in. As Thomas Dixon observes, 'A tear is a universal sign not in the sense that $\mathrm{i}[\mathrm{t}]$ has the same meaning in all times and all places. It 
is a universal sign because it can signify just about anything. ${ }^{.12}$ Hyperbole, unity and passion around global figures offer a kind of grand guignol from which broadsheet newspaper obituaries keep some distance.

The scant critical literature on obituaries proposes various paradigms and purposes. Examining obituaries of French academics and schoolteachers, Pierre Bourdieu analysed their terms of value to propose they demonstrate reproduction of social structures. Their precise, semiconscious models of ideology and teleology-how someone's career develops, or not—give lives a class identity; obituaries provide a constitution for bourgeois reproduction. ${ }^{13}$ Bridget Fowler, following Bourdieu, argues that 'Obituaries should not be seen merely as homage to individuals but as part of a wider play of symbolic power'. She suggests 'We might think of obituaries as commemorative pacts that help explain the inertia [...] of social structures' ${ }^{14}$ We might indeed. But such an approach sees obituaries more as a pact between subject and writer; it assumes readers occupy a willing third point of triangulation, absorbing unreflectively the values and class paradigms of such pacts. I think we don't know enough about how readers read obituaries. For those still reading a daily print newspaper, obituaries arrive as ephemeral texts: what (or who) you read today is succeeded by another set of newly dead lives tomorrow. Reader experiences may be understood in terms of age groups-the older one gets, I think, the more one appreciates the genre of obituaries; they press the question of amor fati, or whether people do anything worthwhile with their lives. They may also induce memento mori, especially if the subject belongs to the reader's age group. The more too one understands that their summation of a life is provisional. You know that especially if you know the deceased, and can see how a whole person gets squashed into a thousand words. You may read all, none or some of a daily's obituaries; you may read a single person's obituary over several newspapers. In that sense, reader response theory applied to obituaries needs to be nuanced. And if you read news online, obituaries no longer appear as a dedicated double page spread; instead, a heading links obituaries from different sections, diffusing the genre-though not necessarily diluting it—into different discursive and cultural domains. ${ }^{15}$

Nigel Starck, who has compared obituarist practices in the US, UK and Australia, speaks for afficionados of obituaries everywhere when he argues, 'There is nothing inherently gloomy about the newspaper obituary page: done well, it should capture life rather than wallow in death.' Starck theorises obituary pacts thus:

The idea is to show, by character study and anecdote, what its subjects were like [...] The discerning obituarist has to eschew the sentimental tendencies and intimacies of the eulogy and tell the life story for an audience of strangers. The further challenge, arising from this necessary estrangement, is that 
those readers should be made to wish-after reading the obituary-that they had known the subject. ${ }^{16}$

His terms evoke a curious psychodynamic-estrangement makes strangers into people whom a reader likes, though not necessarily through likeness. A wish-to-have-known these people is an optative which has similarities with mourning's I-wish-this-person-was-still-alive. But obituary subjects are, for all sorts of reasons, people you may well not know or like, so a response of positive affect seems too simple. As a life narrative is constructed along with character, a philosophical response is also possible: this person was good, capable, admirable. The obituary evokes values, which may well be ideological but, like degrees of sympathy for characters in fiction, may also enable resistances.

My critical interest in obituaries was sparked by an obituary of Martin Wells, a marine biologist who died aged 80 in 2009. ${ }^{17}$ There were reasons why I was interested-Wells was an expert on cephalopods (octopus, squid, nautilus, cuttlefish) and it was his research that established the to my mind fascinating discoveries that octopus taste by touching, and how the respiratory apparatus of the nautilus enables it to move between great depths and shallows. But for all that I celebrated those discoveries, and mourned the loss of the mind that thought to enquire into them, there was something else at work too. It sounded like Martin Wells was a generous person with a happy life. Though marine biologists don't have dry lives in a literal sense, and people who love octopus usually have a sense of play, he was really lively. As the obituary said,

The overused expression 'a good work-life balance' could have been invented to describe Martin. Last year was an especially happy one for him. His first novel, Second Coming, was published; he had six weeks on his yacht, the Sepiola, in the Ionian sea; there was an exhibition of his paintings, and a memorable 80 th birthday party $[\ldots]^{18}$

I rejoiced that an academic could have such a full, happy and entertaining life-there's hope for the rest of us! It wasn't that I wanted to know him or even to have known him but I was glad he'd existed, and I still want not to forget the implications of his existence. The subheading, 'Distinguished biologist inspired by the hidden wonders of marine life', used powerful terms-distinction, inspiration, wonder - that seem to belong to an older era, as Wells had. Especially with subjects aged more than threescore years and ten, one subtle pleasure of obituaries may be how they slide a reader back in time, to historical and linguistic frames in which the reader-and readership-has nostalgic investment. As you read of the recent death of a subject, you feel the gradual death of discourses. 
Another pleasure of obituaries is 'uplift', as one enthusiast put it to me. It is narcissism in that uplift may involve similarity between reader and deceased; it is also super-egoish in that the deceased's life can exemplify virtues which elude the reader (well, me). An example was given to me in the obituary of Necdet Kent, who died in Istanbul in 2002, aged 91. He'd been the Turkish consul general in Marseilles during 1941-1944. One day he was told 80 Turkish Jews had been put on a train bound for a Nazi concentration camp. He rushed to the station and boarded the train. The Nazis told him to get off; he refused, unless his 80 compatriots were allowed off too. The train began to move; at the next station, Gestapo officers again begged Kent to get off. He would not budge. 'Dumbfounded by his uncompromising stance, the Germans let everyone off the train, thus putting an end to this drama. ${ }^{19}$ Necdet Kent then arranged for papers for the 80 to travel to Istanbul, saving their lives-and more, throughout the course of the war. The obituary offered a story so exemplary in courage it weighed more than an anecdote; it seemed to condense biography and show its agency in relation to history (and perhaps romance, in its similarity to the 1942 film Casablanca?).

Obituaries can subliminally offer identity politics that align deceased and reader. But that formulation can be uneven. The New York Times obituaries editor noted defensively that of the c. 155,000 people who die between each edition of the paper, he had room for three, and for historical reasons most of them were white men. ${ }^{20} \mathrm{~A}$ study of obituaries of librarians in the New York Times between 1977 and 2002 revealed that 'Although librarianship is a female-intensive profession, 63.4 percent of the obituaries chronicled the lives of male librarians'. ${ }^{21}$ One day, very unusually, I came across a double spread of female obituaries in The Times. ${ }^{22}$ The four could be described as follows: an actor who was an early Bond Girl; a lion-tamer turned circus-manager; a teacher and human rights activist; a society hostess who had been active in the Resistance. Early on in each piece three of the four were described as being extremely beautiful, which made one suspect glamour secured some of their attention as subjects. But the contingency really struck me. This foursome made an extraordinary tableau of women's lives in the twentieth century, and truth was stranger than fiction. You couldn't or wouldn't make them up as representatives - and yet there they were, having lived. I reflected on what opportunities women made and took, rather than what was supposed to be open to them. Contingency also made me wonder about social history: the women were different ages, arguably different generations (two born in the 1920s, one 1930s, one 1950s) and yet by dying within five days of each other, they were historically connected in a way only obituaries make present, muddling chronology. Given that postmodern and popular history privileges decades as periods of formation-the sixties, 
the noughties-simultaneity of death provides an interestingly random texture. Birth and death dates define us absolutely in memorials; your life becomes a sort of sum, name plus dates. Yet here was significance to set against those mere signifiers. The human rights activist, Natalia Estemirova, had been kidnapped and murdered. The Resistance worker 'gave dinner parties almost to the end'. Two had daughters; one had no children; one had two stepsons. The foursome spoke to biodiversity among women; to strongly-held political beliefs, for which two risked their lives; to the power of costume, in the lion-tamer's top hat, tails, silver cane and thigh-high boots, and the Bond Girl's skimpy robe. Two were illustrated: Zena Marshall was shown in bed with Sean Connery in $\mathrm{Dr} N o$; Estemirova was depicted by photos held up by three women mourners at a rally in her honour in Moscow. There was real and unreal, acting, disguise, truth-telling. Does death the leveller pile up ideological forces when you read contingent obituaries? The seriousness of Estemirova's work-she was investigating human rights abuses in Chechnya when she was abducted and shot-could be contrasted with the frivolity of Marshall's, cast as an exotic face to advertise shampoo. Neither Starck's model of wishing-you-had-known-x nor Fowler's model of class identification applied here. The person or persons responsible for Estemirova's murder are still not clearly identified; in the absence of a proper trial, allegations of cover-up continue ten years later. As long ago as 1986 it was suggested public discourse had become so much a culture of entertainment that politics was increasingly a form of show business: 'The result is that we are a people on the verge of amusing ourselves to death. ${ }^{23}$ Estemirova's was not a natural death or a closed life narrative like the others. Reading her obituary was grim, not amusing.

Obituary pages can play games with time. These four did not die on the same day, but they appear as dead persons on the same day-in that newspaper, since other obituaries appeared on different days in different outlets. This slipperiness of being appears also in obituary illustrations, which in broadsheets are nearly always a photograph. One research project found that obituary photographs may look visually static but show changing social mores: 'The study found that the number of obituary photographs showing the deceased at a much younger age than when he or she died more than doubled between 1967 and 1997. Researchers found women were more than twice as likely as men to have an obituary photo from when they were much younger.' The study's co-author said, 'Our findings suggest that we were less accepting of aging in the 1990s than we were back in the 60s. ${ }^{24}$ So the apparent humanism of obituaries is vulnerable to sexism and ageism. And racism..$^{25}$ Informality and positivity are also more ascendant: 'Gone are the days of stuffy portraits in the obituary section of the newspaper!' exclaims a 2018 blog which 
recommends 'a photo of the deceased laughing, enjoying themselves or engaging in their favorite hobby'. ${ }^{26}$ Nigel Starck sees similar informality in broadsheet obituary prose since the 1980s: 'They have shrugged off the subfusc language of old, introducing in its stead a fusion of irreverent assertion and candid assessment', including being much more open about sexuality, sexual proclivities and activities. For Starck, this makes the obituary better biography: 'Today, though, it is through an unfussed revelation of, and reflection upon, a subject's homosexuality that the obituary achieves a certain grace. ${ }^{27}$ Obituaries are thus slowly adapting to some components of new identity politics.

In a still resonant essay, Barbara Johnson explored the $\mathrm{O}$ of apostrophe: 'The absent, dead, or inanimate entity is thereby made present, animate, and anthropomorphic. Apostrophe is a form of ventriloquism through which the speaker throws voice, life, and human form into the addressee, turning its silence into mute responsiveness. ${ }^{28} \mathrm{O}$-bituaries make the unresponsive dead subject retain voice, life and human form, whilst acknowledging death as a passage into silence. Obituaries for the newly dead reverse apostrophe's making present in favour of elegy's letting go. Or by presenting the life as full circle (from 'child of' to 'survived by'), obituaries combine apostrophe's making present and elegy's letting go.

\section{OBITUARIES AND HUMOUR}

Obituaries commemorate a life at the point where it is completed by death. Yet the completion is also depletion, in the sense that the life is constructed as meaningful precisely at the point where it stops. So there is a psychodynamic of fullness and emptiness, and also a sort of joke: just when a life ends, it makes sense. An older memorialising practice took this irony seriously. Thus Shakespeare's Malcolm says of the repentant Thane of Cawdor, executed for treason, 'Nothing in his life became him like the leaving it' (Macbeth Act I sc. iv, 1-8). At the last minute, literally, you can become yourself more than ever! Contemporary culture allows this irony to be comic. For instance, on September 152008 Trib.com, Wyoming's online newspaper, had an account of Jim Adams who died aged 53:

Jim, who had tired of reading obituaries noting other's courageous battles with this or that disease, wanted it known that he lost his battle. It was primarily as a result of being stubborn and not following doctor's orders or maybe for just living life a little too hard for better than five decades. [...]

He was sadly deprived of his final wish, which was to be run over by a beer truck on the way to the liquor store to buy booze for a date. True to his personal style, he spent his final hours joking with medical personnel, cussing 
and begging for narcotics and bargaining with God to look over his loving dog, Biscuit, and his family.

In lieu of flowers, he asks that you make a sizeable purchase at your favorite watering hole, get rip roaring drunk and tell the stories he no longer can. ${ }^{29}$

There are other variations of this story online, commonly with a protagonist called Fred; its recirculation suggests readers want it to be true, or don't care if it is a fiction. It has been much reprinted in books of trivia and bathroom readers, where its inversion of obituary conventions flirts with comic indignity. It may fit Starck's paradigm-this guy sounds fun though the full obituary reports he behaved badly to women so you might not want to meet him if you're female, teetotal or sober. It may fit Fowler's, if you identify with dead-beats. What's more likeable is the sense of humour: that may originate with Jim, but it's manifested through the obituary's drollery. Deadpan humour puts life into death.

Mark Twain wrote a parody of contemporary obituarists mocking them for mawkishness, ${ }^{30}$ though Twain himself used cliché and sentiment in writing about death. ${ }^{31}$ If sentimentality can be comic, what sentiments can comedy add to the obituary? Some online anthologies of obituaries promise hilarity, though I found them mawkish: 'Laughs wrung from behind a veil of tears are the sweetest laughs of all', as one puts it. ${ }^{32}$ So I turn to the verse obituaries of Private Eye, a British satirical magazine begun in 1961 and edited since 1986 by Ian Hislop. It began as anti-establishment; it is now a counter-establishment institution. Its regular features have included verse obituaries, which until 2010 were written by Barry Fantoni (now retired) under the name E.J. Thribb 17 1/2, a signature on which all sorts of witty variables are played. Printed in 'Poetry Corner' under the sombre title In Memoriam, ${ }^{33}$ the subjects are well-known for something public, often represented by a memorable catchphrase or signature tune. Thribb has two memorable catchphrases of his own: the opening-'So. Farewell then' and 'That was your catchphrase', often a volta or turning point in the free verse. Fantoni said in an interview that Thribb parodies the media's often excessive reaction to death:

\footnotetext{
'It's that celebration of very often quite worthless people. That's the thing about the catchphrase-in other words, that's what really sums you up and you weren't anything more than that.' He was pleased with one about the actor Brad Dexter. 'He's the one in the Magnificent Seven who no one can ever remember', he says, failing to suppress a laugh. 'There's something hugely significant about that in comedy terms. ${ }^{34}$
}

An intimacy with readers is established through running jokes, especially about the Magnificent Seven; through recognition of the catchphrase, often 
embedded in popular culture; through sharing the jokes of Thribb's signature variations; and through a pair of intimates of Thribb, Keith and Keith's mum, who comment like a Greek chorus. Consistent layout provides a visual similarity that makes familiarity into intimacy. You know what's coming. But you also don't know what's coming — and the unpredictability is fun.

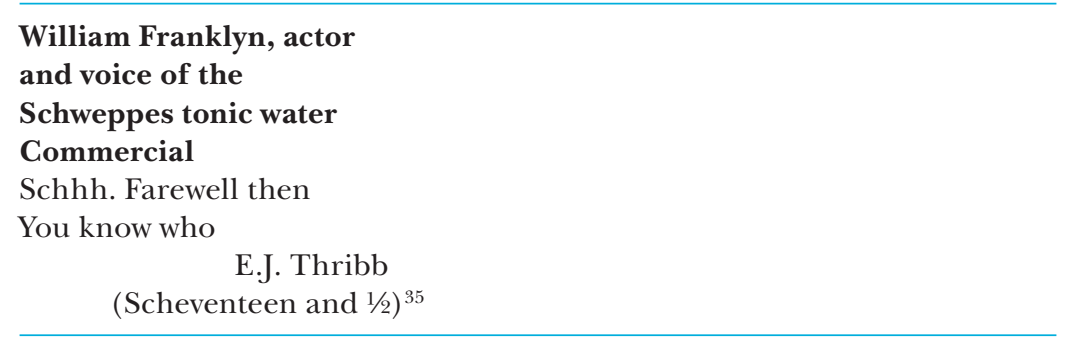

Occasionally the dependable celebration of banality is subject to surprise through seriousness. Thribb bids farewell to Slobodan Milosevic and Humphrey the cat, official pet at 10 Downing Street, the British Prime Minister's residence:

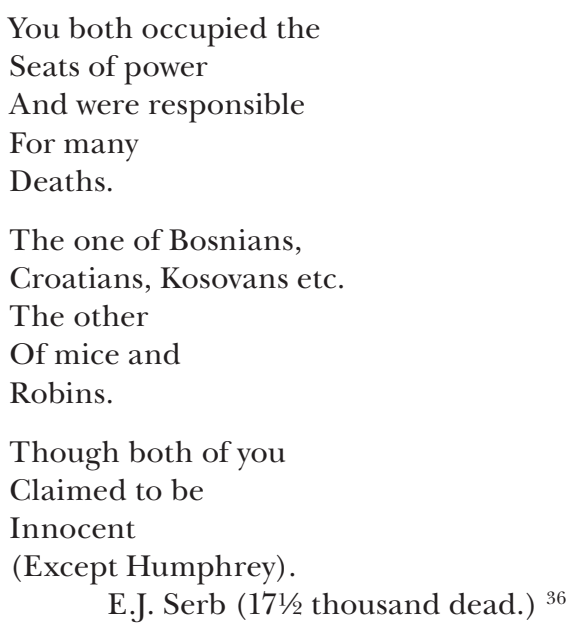

A collection of these obituary poems, published in 1978, mocks the publicity of back-cover blurb conventions: 'Of the private life of $\mathrm{E} J$ Thribb, the man behind the myth, very little is known. A retiring person, he jealously guards the secrets of his private life, a privacy shared only with his friend, Keith, and Keith's mum. ${ }^{37}$ Keith is often a device 
to extend irony, as in 'Lines of the Departure from Office of President George W. Bush':

We never did discover

What the 'W'

Stood for.

Keith says it was

'Warmonger'.

Keith does say

Some very silly things

At times.

Eric J. Thribb $(171 / 2)^{38}$

Keith's mum represents an older vintage of popular culture, referencing things on the edge of being forgotten, like Frankie Lane, famous for hit themes for 1950s American television shows including Rawhide and Champion the Wonder Horse:

\section{But Keith's}

Mum says that

Her favourite

Was Ghost Riders

In The Sky.

And now

You've become

One of them.

All together now-

Yippee-yi-o

Yippie-yi-ay...

E.J. Thribb $(78 \mathrm{rpm})^{39}$

Jokes about catchphrases and theme tunes ironise how the obituary constructs intimacy: the catchphrase enters sociolects and idiolects, public speech and everyday conversation, represented by Keith and Keith's mum. An intimate public gets a voice through linguistic and musical phrases; the bardic personality of Thribb speaks for and to readers who share intimacy through jokes, public parody, and bonds to older worlds of radio and television shows, many of which have also died off.

Various theorists explain humour in terms of its production of superiority, incongruity, relief, and play. All fit: superiority and relief remind 
the reader they're still alive, like the fat scullion in Sterne's Tristram Shandy who when told someone is dead says, 'So am not I. ${ }^{40}$ Incongruity defuses disbelief at death and packages abjectness, or that deep psychoanalytic revulsion that makes us aware of being alive, according to Julia Kristeva who argues the corpse is the ultimate abject thing. ${ }^{41}$ Even more useful, picking up play, is Henri Bergson, who sees humour as a way of resisting rigidity. He argues there is 'a certain rigidity of body, mind and character, that society would still like to get rid of in order to obtain from its members the greatest possible degree of elasticity and sociability. The rigidity is the comic, and laughter is its corrective. ${ }^{42}$ Protagonists of obituaries are indeed rigid-we refer irreverently to the dead as 'stiffs'. Playful humour deflects and reduces readers' unease at death; it reassures us we don't need literary rigour to wrap up rigor mortis. Models of the public sphere usually assume its inhabitants are living, but obituaries can keep the dead alive, as dead serious and dead funny. As E.J. Thribb puts it 'In Memoriam Howard Hughes' ${ }^{43}$

\author{
So. Farewell then \\ Howard Hughes \\ Mystery millionaire. \\ It would seem that \\ You are dead \\ But are you? \\ We have been hoaxed before \\ So why not now? \\ But then. Does \\ Anyone really die? \\ This is the enigma.
}

\title{
OBITUARIES OF ANIMALS AND OTHER OTHERS
}

From print obituaries of establishment figures and comic counterparts, I turn to some non-human obituaries to pursue what obituaries do. Human attachments to animals can be emotionally powerful, and pet deaths raise questions about what sorts of grief, ceremony and tribute are desired, accepted and valued by the pet's human companions or their society, especially in comparison to the grief, ceremony and tribute allocated to dead humans. Pet obituaries have become popular online, though they had non-digital precedents and still have offline forms too. ${ }^{44}$ Scientists 
have long debated whether animals feel emotion, and scholars in animal studies have explored assumptions that they do. ${ }^{45}$ 'Even if joy and grief in dogs are not the same as joy and grief in chimpanzees, elephants, or humans, this does not mean that there is no such thing as dog joy, dog grief, chimpanzee joy, or elephant grief. ${ }^{36}$ Ontological uncertainty about the feelings of animals takes second place to descriptions in which animal pleasures are deduced from actions. When a rescue black labrador/ pointer/greyhound cross called Brian died aged 11, Lee Dibella wrote an obituary described as 'The Most Heartbreaking, Honest Dog Obituary You've Ever Read'. ${ }^{47}$ A video version went viral. ${ }^{48}$

At the core of the 300 words is this:

A lover of couches and blankets, Brian had many hobbies. Some of Brian's favorite activities included barking at things not there, cuddling alongside you, taking over his mother's bed, licking his butt, acting like a spazz when it was time to be fed, and trying to figure out who exactly was 'the good boy'. In his spare time, Brian dreamt violently, thrashing his legs, presumably chasing dastardly felines or squirrels who dared enter his dreams. The quickest way to Brian's heart was with a quality scratch of his rear, and a rub of his belly.

Traces of anthropomorphism-hobbies, good boy, presumably chasing cats-coexist with an embodied canine world view. This section is followed by a description of human loss:

Brian will be greatly missed by many, but none more so than his mom. Through thick and thin, she loved him with all her heart, and though the pain she feels without him is great, it in no way would compare to having never had him in her life.

There is some of the rhetorical distancing that obituaries for humans adopt - the human is referred to in the third person-but human grief is explicitly included. So too is possible interpellation for the reader, since closeness is couched in second-person terms: 'cuddling alongside you'. The author was turned away from her local newspaper on the grounds that obituaries were 'only for humans'; the humanity within interspecies relations is given space in pet obituaries.

Pet cemeteries offer a range of death-related texts: templates, obituaries, even poems ${ }^{49}$ One hosts an obituary page, http://heavenspets.com/ obituaries/. The tributes include one for Luke, a German Shepherd: 'He once held off an entire battalion of Confederate re-enactors at Fort Jackson who had become lost and were marching toward his boat.' Other courageous acts during Hurricane Katrina make Luke sound like you'd be glad to meet him, unless you were a re-enactor. Before the photo gallery, the written obituary ends 
Nancy will tell you Dave spoiled that dog, and Dave will tell you that Nancy spoiled the dog, but honestly, words can never express the depths of our grief or the gratitude that we feel for the privilege of being his people.

'Words can never express': the inarticulacy of bereavement takes on a different inflection in pet obituaries. Body language is crucial-a belly rub, an ear tickle-as human companions review the animal's life in embodied terms in which touch (both ways) conveys love. Touch is important in consolation between humans too, not least in 'touching' tributes, and the pet obituary shows an intriguing levelling between companion species, in that since animals can't talk (though they can certainly communicate), the wordlessness of grief puts humans in similar mode to their dead companions. 'Mere words cannot possibly describe our feeling of loss since you've been gone. Our home was once warm and vibrant, perfectly accented by your wagging tail, and drooling mouth', another obituary from the same site begins (to Satchmo Nobles, a bloodhound). Pain, love, miss, loss: the vocabulary is short and intense. These examples are American, but similar ones can be found in British culture. For example, a tribute to a tortoise:

A firm scratch of his leathery chin would encourage his head to emerge slowly and his beady eyes to close in bliss [...] Seven years and five tortoises later, we still miss the click of his nails on the kitchen floor, the scrape of his shell on the doorframe and the rhythmic thump of a shoe getting a thorough seeing to. 'But can you love a tortoise?' people ask. You absolutely can. ${ }^{50}$

Part of the growth of pet obituaries relates to inclusion of animals as family members. In 2013, Bring Your Child to Work Day was adopted in the UK; in 2014, Bring Your Dog to Work Day became established. Increasing the contexts in which pets count visibly as family opens up questions of seeing animals as quasi-human, or as members of species to whom connection may be as close or closer than to other humans. In 2019, a woman who lost her job on the day her terrier died started a petition calling for bereavement leave when family pets die. It was 'like losing a member of the family', she said. ${ }^{51}$ Adopting human models of relationship-people with small dogs often select a mother-baby paradigm-translates companion species' emotional economies of care which, at the end of life, can also help assuage difficult decisions about euthanasia. Wanting pets to have the ideological support and legal recognition afforded to family, human companions increasingly view pets as feeling subjectivities whose lives merit memorialisation. The gap can be especially narrow between humans and our close relatives, primates. A video with nearly twelve million views shows an elderly chimp dying in captivity, who is visited by 
her old friend, a human. This is a deathbed rather than an obituary, but its beautiful and tender reciprocity, conveyed by touch, gesture and emotional sounds, conveys species equality through similarity of dying. 'Her trembling hand (-). Just like human grandmas', says one comment. ${ }^{52}$ Primates who become more like humans by learning sign language or human words have been given obituaries: thus Washoe, commemorated in The New York Times in 2007, and Koko, a gorilla whose death notice is explicitly described as an obituary. ${ }^{53}$ These primates temporarily count as human in a slightly different form of anthropomorphic connectivity from that usually accorded to non-talking animals. They warrant obituaries because having shared words with humans, written tributes recognise their exceptionality.

\section{ECO-OBITUARIES?}

If the obituary is a genre in which dignity and feeling can be combined, why should it be restricted to humans? Or to animal members of human families? When Pluto was declassified as a planet in 2006, one newspaper cast the news as an obituary: 'Pluto the planet, 76, died Thursday in Prague, Czech Republic, when it was killed by the International Astronomical Union [...]. ${ }^{54}$ In a curious twist, the astronomer who 'discovered' Pluto was re-associated with it in a space-travelling memorial (hard to differentiate from space junk?):

In memory of the first American to discover a planet in our solar system, the piano-sized New Horizons spacecraft carries a small aluminum canister containing some of Tombaugh's cremated remains, donated by his family. These remains will fly past Pluto with New Horizons on July 14, 2015, and then on past Kuiper Belt objects in the succeeding years. New Horizons will eventually escape our solar system altogether and enter interstellar space. As such, Tombaugh's remains have become the first to be launched to the stars. ${ }^{55}$

In 2019, the first of Iceland's glaciers to be declassified, Okjokull, had a text memorial in the form of a mourning plaque which also records $\mathrm{CO} 2$ levels at the time of installation, and carried a chastising message couched as a letter to the future:

Ok is the first Icelandic glacier to lose its status as a glacier.

In the next 200 years all our glaciers are expected to follow the same path.

This monument is to acknowledge that we know what is happening and what needs to be done.

Only you will know if we did it. 
Those who gathered to lay the plaque were described as mourners, recognising the validity of eco-grief.

'People felt this was a real loss, and that it deserved some kind of memorial', Dr Boyer said. 'Plaques recognise things that humans have done, accomplishments, great events. The passing of a glacier is also a human accomplishment-if a very dubious one-in that it is anthropogenic climate change that drove this glacier to melt. ${ }^{56}$

If we accept an expansion into non-human subjects, why could the obituary not be a highly relevant genre for environmental writing in the Sixth Extinction, this period of now in which millions of species are vanishing? As it dawns on humans that life forms are disappearing-almost all of which have lived longer on Earth than humans-can the obituary be adapted for activist purposes?

In the Anthropocene, nature writing is increasingly full of elegy. ${ }^{57}$ Above all there is grief for vanishing life forms and dying ecosystems. As Adam Nicholson puts it in The Seabird's Cry (which won the Wainwright Book Prize in 2018) 'there is no doubt about it: this is an age of loss'. ${ }^{58}$ Is obituary a useful genre in commemorating lost species? There are I think two reasons why not, or not yet. First, obituaries presume a habeas corpus, a body; extinctions remove that.$^{59}$ Second, the testamentary power of obituaries sits on a bedrock of facts-though occasionally prepared obituaries are published prematurely in error, the broadsheet obituary is fact-checked, usually scrupulously; the scientific facts of the Sixth Extinction are proven, but also denied. The conjectural nature of prediction, with its revision of worst-case scenarios and dates, sits ill with the obituary's convention of ritual completion, its rites of ending. Nonetheless, some elegy comes close to obituary. Thus Edward O. Wilson ends a chapter titled 'An Elegy for the Rhinos' by visiting the Cincinnati Zoo to see two Sumatran rhinos. An optimistic estimate suggests there may be a hundred left in the wild. It is night; the rhinos are still as statues. Wilson draws close to touch them, 'once each, quickly and softly, with the tips of my fingers. My feeling at that moment was spiritual and lasting, one I can't explain in words to you or even today to myself. ${ }^{\prime 60}$ Like the power of touch in pet obituaries, connectivity exceeds words.

There is one eco-obituary, however, which went viral in 2016:

The Great Barrier Reef of Australia passed away in ... after a long illness. It was 25 million years old. [...]The reef was born on the eastern coast of the continent of Australia during the Miocene epoch. Its first 24.99 million years were seemingly happy ones, marked by overall growth. 
The obituary, written by Rowan Jacobsen, used the research of leading coral biologist Charlie Veron, especially his elegiac talk to the Royal Society about how the world's largest living structure is dying and is likely to have gone-dissolved by acid seas-by 2030. The reef "provided some of the most thrilling marine adventures on earth to humans who visited. Its otherworldly colours and patterns will be sorely missed. [...] To say the reef was an extremely active member of its community is an understatement'. There was a big response on social media, not all of it positive: some missed the satire, some denounced the piece as clickbait. Others insisted on the value of hope:

Terry Hughes, the Australian researcher whose surveys of the damaged reef this summer led to impassioned pleas to help protect it, put it bluntly: 'You don't write the obituary of a loved one when they are diagnosed with a serious illness-you help them fight for their life. ${ }^{61}$

This obituary was not the first: The Guardian posted a multimedia obituary of the Great Barrier Reef in 2014, ${ }^{62}$ which drew attention to the massive impact of the mining industry, exporting coal from big ports on the reef with ships of vast tonnage to sustain fossil fuel economies elsewhere in the world. But it didn't catch on. Why did Jacobsen's? Its success, I think, comes from how impeccably it grasps the conventions of an obituary, even down to its grammar. It repurposes the anthropocentrism which has caused the Anthropocene, and how obituaries assign social significance to their subject. Critics disliked parody applied to something deadly serious, but irony underlined that deadliness.

\section{NOT NEARING THE END}

Twenty-first century evolutions of the obituary relate to new publics and demotics created by digital and social media: exactly how is a question too big to answer here and I think the answers are not simple. Nigel Starck argues that the key change was not digitality but a real world event: the attack on the World Trade Center in New York on 11 September 2001, after which the New York Times published short obituaries of the victims. Terrorism rather than the internet democratised the obituary: 'An unpretentious existence can today achieve a measure of fame, simply through a random assault on its very unpretentiousness. ${ }^{63}$ One can observe that the emergence of 'Ordinary Lives' in broadsheets seems to suggest a distinction from the genre of the obituary section, as if by implication those subjects were Extraordinary Lives. But in practice the 'ordinary lives' are narratives of great 
social contribution, some nationally, most locally. The 'ordinary lives' reverse imagined community, which classically works towards wider constructs like race, ethnicity or nation: through the obituary, imagined community is recognised as made up of component individuals, or Other Lives. They press the question of who counts as 'important'? And why?

Nonetheless, Other Lives, like pet obituaries, follow many of the traditions of the formal written obituary. To confer dignity they copy in part the official detachment of the Obituaries section. They also copy its narrative model, shortened, with a focus on virtues; there is nothing negative. Explaining the difference, The Guardian says 'Obituaries pages traditionally describe and celebrate the lives of the great and good, the famous and infamous. There is another type of life that deserves noticing: people less in the public eye, or lives lived beyond formal recognition'. One significant difference is that 'Ordinary Lives' are written by friends, relatives or partners of the deceased. The writers wish to commemorate; they are not paid to. Hence 'deserving notice' needs some literary dispassion to achieve. Though they can and do accommodate emotion, these obituaries generally reduce the eulogy's explicit function of praise, for which there are other outlets and memorial forms. 'Other Lives', like pet obituaries, have genre markers which mean they are read and understood as obituary forms. Typically pet obituaries combine micronarratives-a pet's escapes, crimes, character quirks-and affective highlights-expressions of love, endearing habits, loss. This is similar to eulogy, but if published as an obituary, is literarily distinct. Nonetheless, by expanding the demographic of obituaries beyond the supposedly great and the good, ordinary lives and pet obituaries extend posthumous notice to wider groups, dissolving the old power of gatekeepers.

One obituary writer says 'an obituary is [a] chance to reach out with a report of a life lived and engaged in a community'. But he also notes that "concern about "identity theft" is prompting some to recommend not providing complete information-such as the date of birth-in an obituary'. ${ }^{64}$ An obituary's accurate summation of a life is important for history: human ambition will ensure it future copy, and interest in biography will ensure it future readers. Although it has clearly evolved as a genre, its broadsheet template stays recognisably stable-providing newspapers survive in a 'post-truth' world. New forms like the pet obituary acquire solidifying protocols and advices. Yet the potential of obituary for ecological writing - perhaps in dialogue with survival and revival—is just beginning. 


\section{WORKS CITED}

Baines, Barry. Ethical Wills: Putting Your Values on Paper. Cambridge, MA: da Capo Press, 2002.

Barry, Elizabeth. "'From Epitaph to Obituary": Death and Celebrity in Eighteenth-Century British Culture.' International Journal of Cultural Studies 11:3 (2008) 259-275.

Bekoff, Mark. 'Animal Emotions: Exploring Passionate Natures.' BioScience 50:10 (2000) 861-870.

Bergson, Henri. Laughter: An Essay on the Meaning of the Comic. Trans. Cloudseley Brereton and Fred Rothwell (1900). London: Macmillan, 1935.

Bourdieu, Pierre. The State Nobility: Elite Schools in the Field of Power. London: Polity Press, 1996.

Brant, Clare. 'Underwater Lives: Humans, Oceans, Species.' British Society of Literature and Science Conference Keynote, unpub, 2019.

Brisbane, Arthur S. 'The Science of Obituaries: Dead Pools, Obits in the Can and More.' New York Times, April 16, 2012: https://publiceditor.blogs.nytimes.com/2012/04/16/thescience-of-obituaries-dead-pools-obits-in-the-can-and-more/.

Burrell, Ian. 'Forza Fantoni! The Art of Private Eye's Cruel Cartoonist.' The Independent 6 April 2009.

Crisp, Quentin. The Naked Civil Servant. London: Jonathan Cape, 1968.

deMello, Margot. Animals and Society: An Introduction to Human-Animal Studies. NY: Columbia University Press, 2012.

Dilevko, Juris and Lisa Gottlieb. 'The Portrayal of Librarians in Obituaries at the End of the Twentieth Century.' The Library Quarterly 74:2 (April 2004) abstract.

Dixon, Thomas. 'Waterworks.' Aeon, nd. https://aeon.co/essays/read-it-and-weep-what-itmeans-when-we-cry.

Finn, Natalie. 'Remembering the Madness on the Day Michael Jackson Died.' E-News June 252019.

Fowler, Bridget. 'Mapping the Obituary: Notes towards a Bourdieusian Interpretation.' In: Lisa Atkins and Beverley Skeggs (eds.), Feminism after Bourdieu. Oxford: Blackwell, 2004.

Johnson, Barbara. 'Apostrophe, Animation, and Abortion.' Diacritics 16:1 (Spring 1986) $28-47$.

Jiwani, Yasmin. 'Obituaries as Markers of Memory: Grievability and Visibility in Representations of Aboriginal Women in the National Canadian Imaginary.' Cultural Studies: Critical Methodologies 16:4 (2016) 387-399.

Kitch, Carolyn and Janice Hume. Journalism in a Culture of Grief. London: Routledge, 2008.

Kristeva, Julia. The Powers of Horror. An Essay on Abjection. Trans. Leon S. Roudiez. NY: Columbia University Press, 1982.

Lehrer, Tom. That Was The Year That Was. Reprise/Warner Bros. Records, 1965.

Macdonald, William. 'From the Death Desk: Why Most Obituaries are Still of White Men.' The New York Times, March 82018.

Messent, Peter. The Short Works of Mark Twain: A Critical Study. Philadelphia: University of Pennsylvania Press, 2001.

Nicholson, Adam. The Seabird's Cry: The Lives and Loves of Puffins, Gannets and Other Ocean Voyagers. London: HarperCollins, 2017.

Postman, Neil. Amusing Ourselves to Death: Public Discourse in the Age of Show Business. London: Penguin Books, 1986.

Private Eye Annual, ed. Ian Hislop. London: Private Eye Productions Ltd, 2005-2017.

Powell, Kay. 'Eight is Enough.' The Atlanta Journal-Constitution, August 25, 2006.

Scodel, Joshua. The English Poetic Epitaph: Commemoration and Conflict from Jonson to Wordsworth. Cornell: Cornell University Press, 1991. 
Sterne, Laurence. The Life and Opinions of Tristram Shandy, Gentleman. 7 vols. London: Becket \& DeHondt, 1759-1767.

Starck, Nigel. Life after Death: The Art of the Obituary. Victoria: University of Melbourne Press, 2006.

Starck, Nigel. 'Obituaries.' In: Bob Franklin (ed.). Pulling Newspapers Apart: Analysing Print Journalism. London: Routledge, 2008, 91-101.

Starck, Nigel. 'Sex after Death: The Obituary as an Erratic Record of Proclivity.' Mortality: Promoting the Interdisciplinary Study of Death and Dying 14:4 (2009) 338-354.

Thribb, E.J. (17) [sic!] So. Farewell Then... and Other Poems. London: Elm Tree, 1978.

Twain, Mark. Post-Mortem Poetry (1870) http://www.online-literature.com/twain/3260/.

Wilson, Edward O. Half-Earth: Our Planet's Fight for Life. New York: W.W. Norton, 2016.

\section{Websites}

https://www.bbc.co.uk/news/world-europe-49345912

https://beyondthedash.com/blog/obituary-writing/how-to-choose-the-right-obituaryphoto/7217

https://publiceditor.blogs.nytimes.com/2012/04/16/the-science-of-obituaries-deadpools-obits-in-the-can-and-more/

https://www.economist.com/obituary/2009/03/26/jade-goody/

http://obituaryforum.blogspot.com/2007/

https://www.rt.com/usa/362828-great-barrier-reef-obituary

https://www.societyofprofessionalobituarywriters.org/

https://www.telegraph.co.uk/news/obituaries/1408262/Necdet-Kent.html.

https://www.theguardian.com/tone/obituaries

https://www.theguardian.com/science/2009/feb/25/obituary-martin-wells

https://www.wideopenpets.com/get-ready-to-read-the-most-heartbreaking-yet-true-dogobituary/

\section{ABOUT THE AUTHOR}

Clare Brant is Professor of Eighteenth-century Literature and Culture at King's College London, where she also co-directs the Centre for Life-Writing Research. She co-edits the Palgrave series Studies in Life Writing, and has published widely. She proposes to write her own obituary to make sure she has one, to save anyone else the bother and to preserve a few of her best jokes. Email: Clare.brant@kcl.ac.uk.

\section{NOTES}

1 Crisp, Naked (222).

2 The Times, The Daily Telegraph, The Guardian, The Independent, each with a political flavour (respectively, establishment, right, left, centre.) Originally known as broadsheet because they used larger pages than tabloids (like folio to quarto: broadsheet dates back to 1712). The term lingers, though all except The Daily Telegraph have downsized to smaller paper. In Britain, 'tabloid' is often a synonym for sensationalist journalism, and 'broadsheet' for serious. 
3 Quoted on Andrew Losowsky, 'Last Writes', 2004 blog, webpage.

411 January 2016.

5 https://www.theguardian.com/music/2016/jan/11/obituary-david-bowie.

6 Brisbane, 'The Science of Obituaries'.

7 Ibidem.

8 Starck, 'Obituaries' (92).

9 Barry, 'From epitaph to obituary' (259-275). My thanks to James Metcalf for this reference.

10 A conflict especially visible in The Economist, following its obituary. See https://www. economist.com/obituary/2009/03/26/jade-goody.

11 This page has disappeared, and weirdly the website skips 2009 altogether. If you search under 'death', this immortalising quotation comes up: 'Like Michelangelo, he said, "I know the creator will go, but his work survives. That is why to escape death, I attempt to bind my soul to my work."' https://www.michaeljackson.com/news/rememberingmichael-jackson-2/. See Finn, 'Remembering the Madness', for an overview.

12 Dixon, 'Waterworks'.

13 Bourdieu, State Nobility (47-53).

14 Fowler, 'Mapping the Obituary' (149).

15 For example https://www.theguardian.com/tone/obituaries draws in obituaries from world news, film, sport, farming and publishing. Accessed 26 August 2019.

16 Starck, 'Obituaries' (93).

17 https://www.theguardian.com/science/2009/feb/25/obituary-martin-wells.

18 Ibidem.

19 Daily Telegraph 26 Sept 2002; https://www.telegraph.co.uk/news/obituaries/1408262/ Necdet-Kent.html.

20 Macdonald, 'Death Desk'.

21 Dilevko and Gottlieb, abstract.

22 The double page is not recuperable in online format. 'Zena Marshall.' The Times, 18 July 2009, 84; Natalia Estimorova, ibid, 86. The Times Digital Archive, http://tinyurl. galegroup.com/tinyurl/BaYsD3.

23 Postman, Amusing Ourselves to Death (3).

24 Keith Anderson of Ohio State University quoted in Ohio State News, May 12 2009; https:// news.osu.edu/obituary-photos-suggest-growing-bias-against-aging-faces/.

25 The New York Times prints obituaries of people of colour (from 1851 on) each February, Black History Month, in a supplement titled 'Overlooked'.

26 https://beyondthedash.com/blog/obituary-writing/how-to-choose-the-right-obituary-photo/7217.

27 Starck, 'Sex after Death' (338).

28 Johnson, 'Apostrophe' (30).

29 Website now unavailable in the EU because of General Data Protection Regulation 2016/679/.

30 Twain, 'Post-Mortem Poetry' (1870), http://www.online-literature.com/twain/3260/.

31 Messent, Short Works (193).

32 https://www.everplans.com/articles/10-funny-thoughtful-and-extremely-cleverobituaries.

33 And allusive: Tennyson's In Memoriam A.H.H. (1850), usually known just as In Memoriam, is one of the most canonical poems of personal mourning in English literature.

34 Burrell, 'Forza Fantoni!'.

35 Private Eye Annual, 2007 (20).

36 Private Eye Annual, 2006 (81).

37 E.J. Thribb (17) [sic!] So. Farewell Then... and Other Poems, London: Elm Tree 1978; blurb from www.trashfiction.co.uk/so_farewll_then.html. 
38 Private Eye Annual, 2009 (27).

39 Private Eye Annual, 2007 (20).

40 The someone is Tristram's brother Bobby. Sterne, Shandy (Vol. III, ch. 3, VIII).

41 Kristeva, Powers of Horror (4).

42 Bergson, Laughter (25). Many thanks to Hope Wolf for alerting me to this. See also Aaron Smuts' digest of humour theories at http://www.iep.utm.edu/humor/.

43 Quoted on www.trashfiction.co.uk/so_farewell_then.html.

44 Scodel, Joshua, 1991 discusses pet memorials, including Byron's epitaph to his dog Boatswain. My thanks to James Metcalf for this reference. Mr. Tibs, a ginormous cat who lived at Post Office HQ, had an obituary in Post Office Magazine when he died in 1964. See https://www.postalmuseum.org/blog/the-post-office-cats-150/\#.

45 See deMello, Animals and Society, 'Love and Grief' (157-8).

46 Bekoff, 'Animal Emotions' (868).

47 https://www.wideopenpets.com/get-ready-to-read-the-most-heartbreaking-yet-truedog-obituary/.

48 https://www.youtube.com/watch?v=hCzbvkbDOfs.

49 https://www.rossendalepetcrem.co.uk/poems/.

50 https://www.theguardian.com/lifeandstyle/2015/jul/11/readers-pet-obituaries-herelies-fluffy-rip.

51 https://www.bbc.co.uk/news/uk-scotland-glasgow-west-49346408.

52 https://www.youtube.com/watch?v=EJJVGasSHK0.

53 https://www.thecut.com/2018/06/koko-the-gorilla-dies-obituary.html; https://www. nytimes.com/2007/11/01/science/01chimp.html.

54 Powell, 'Eight is Enough'.

55 Johns Hopkins Applied Physics Laboratory press release, 3 February 2006; https://www. jhuapl.edu/PressRelease/060203.

56 https://www.bbc.co.uk/news/world-europe-49345912.

57 Brant, keynote, 2019 covers this literature in more detail.

58 Nicholson, Cry (349).

59 Museums are full of taxidermy specimens of the bodies of extinct animals, it's true-see

Rosamond Purcell, Swift as a Shadow: Extinct and Endangered Animals (Boston: Houghton Mifflin, 1999). My thanks to Jane Wildgoose for this point and reference. But the Sixth Extinction is of a different order. The vanishing of pollinators, invertebrates, amphibians, birds, animals and other life forms leaves no bodies.

60 Wilson, Half-Earth (33).

61 https://www.rt.com/usa/362828-great-barrier-reef-obituary.

62 https://www.theguardian.com/environment/ng-interactive/2014/mar/great-barrierreef-obituary.

63 Starck, 'Obituaries' (91).

64 https://www.obituaryguide.com/writingtips.php. 